\title{
フラクタル構造を利用した耐久性超撥水 プラスチック膜
}

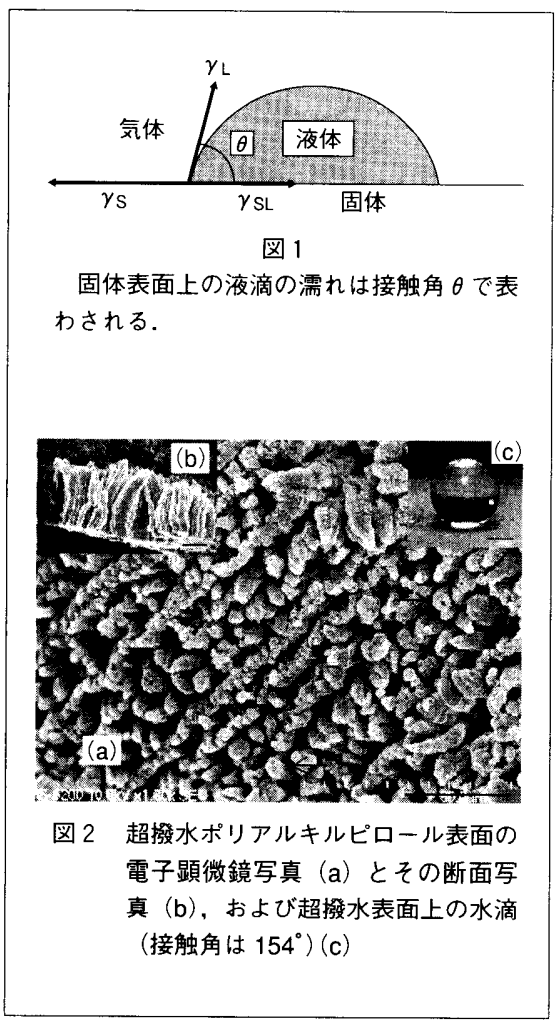

\section{1. はじめに}

水も油も完全にはじく表面ができた ら!その技術的/社会的インパクトの 大きさは計り知れないであろう。それ は污れの付かない表面になるはずであ るから，壁／屋根材，自動車／電車， 航空機などの車体材料, 台所の流し周 辺材料などの構造材から，傘／衣服， テーブルクロスなどの日常品に至るま で, 大変幅広い応用が期待される。本 稿では, フラクタルという数学的概念 を使ってそれを実現する方法, そして それを実用化するための課題について 述べる。

\section{2. 濡れを支配する二つの因子}

濡れは，化学的因子と表面の微細な 構造因子の二つに支配されている。化 学的因子は, 平らな表面上の接触角を 決める. 表面の微細な山凸構造は実表 面積を増大させ，その接触角を強調す る働きをする．図 1 に，液滴が平らな 固体表面上にのっている様子を示す. 接触角 $(\theta)$ は, 固体と液体の表面張 力および固／液の界面張力の釣合いに よって決まり, 次の Youngの式が成 り立つ。

\section{$\gamma_{\mathrm{S}}=\gamma_{\mathrm{SL}}+\gamma_{\mathrm{L}} \cos \theta$ or} $\cos \theta=\left(\gamma_{\mathrm{s}}-\gamma_{\mathrm{sL}}\right) / \gamma_{\mathrm{L}}$

ここで $\gamma_{\mathrm{s}}, \gamma_{\mathrm{sL}}, \gamma_{\mathrm{L}}$ はそれぞれ固体, 液体の表面張力および固／液の界面張 力である：表面の微細な凹凸構造のた めに実表面積が $\mathrm{r}$ 倍になったとする と，上記の式（1）は

$\cos \theta_{\mathrm{f}}=r\left(\gamma_{\mathrm{S}}-\gamma_{\mathrm{SL}}\right) / \gamma_{\mathrm{L}}$ $=r \cos \theta$ (2)

と変形される。ここで $\theta_{1}$ は粗い表面 上での接触角である，rは常に1より 大きな正の数であるから, $\cos \theta$ が正 $\left(\theta<90^{\circ}\right)$ 偩 $\left(\theta>90^{\circ}\right)$ かによっ て, $\cos \theta_{\mathrm{r}}$ はより大きな正または負の 值となる．つまり表面が粗くなること によって，濡れる表面はより濡れるよ うになり，はじく表面はよりはじくよ うになるのである.

\section{3. フラクタル表面の濡れと超

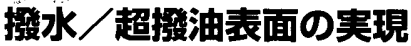

実表面積を増大させて，濡れの傾向 を強調するという観点からみれば，フ ラクタル表面は一つの理想的な表面で ある.フラクタル構造においては, 大 きな凹凸の中に小さな凹凸があり，そ の小さな凹凸の中にさらにより小さな 凹凸があるといった具合に，凹凸構造 が入れ子になっており, 大変大きな表 面積を与える，従って，もし表面をフ ラクタル構造にすることができれば， 極端に濡れたりはじいたりする性質が 期待できるであろう。このような発想 を基に, 我々はまずフラクタル表面の 濡れを理論的に解析し, 次いでその理 論によって得られた結果を実験的に実 証した ${ }^{(1)}$.

製紙用中性サイズ剤の原料は，アル キルケテンダイマー (AKD) と呼ばれ る一種のワックスである。このワック スを融液から結晶化させて SEM 観察 すると，大きな凹凸の中にさらに小さ な山凸の形状が見え，構造がフラク夕 ル的であることが分かっていた。 AKDの精製, 結晶化の条件などを工 夫することにより，水滴がころころと 表面を転がる超撥水材料を開発するこ とに成功した。この表面は，接触角 $174^{\circ}$ という世界一の值を示す ${ }^{(1)}$.

フラクタル構造を有する陽極酸化ア ルミニウム表面をフッ素系撥油剤で覆
うことにより，菜種油に対する接触角 が $150^{\circ}$ 以上の超撥油表面の作製も可 能である ${ }^{(2)}$.

\section{4. 耐久性超搬水表面への挑戦}

我々の研究に端を発して, 表面の微 細凹凸構造が濡れに大きな効果を発揮 することが理解され，その後数多くの 超撥水表面に関する研究がなされた。 最近では lotus effect（蓮の葉効果）と 呼ばれて，世界中で研究が盛んになっ ている，しかし残念ながら，まだ超撥 水表面が実用化された例はない。その 最大の理由は, 超撥水表面の耐久性に ある。例えば，先の AKD ワックスの 場合には, 融点が低い $\left(\right.$ 約 $\left.65^{\circ} \mathrm{C}\right) こ$ と, 有機溶媒に溶けること, もろいこ となどが原因で，2３筒月で超撥水 性を失ってしまう。他の材料に関して も，それぞれ何らかの耐久性の問題を有 しており，それが実用化を阻んでいる。

筆者らは極最近, AKD ワックスの 耐久性を向上する目的で，耐熱性と耐 溶片性を有するプラスチック(ポリア ルキルピロール）を電解酸化重合法で 合成し, 少なくともこれら二つの項目 に関する耐久性を有するフラクタル表 面を得ることに成功した ${ }^{(3)}$. その表面 の電子顕微鏡写真と, 表面上の水滴を 図 2 に示す.しかし,このポリマーの 薄膜はまだ機械的にもろく, 引っかき などに弱い. 現在その改良の研究を続 けている.

これまで超撥水表面の研究は数多く なされているが, 超撥油表面の研究は 極めて少ない. 我々は今後, こちらの 研究でも耐久性に優れたものを開発し たいと考えている。これらの研究をで きるだけ早く完成し，実用化するのが 筆者らの夢である.

(原稿受付 2005 年 11 月 1 日) 〔过井薫 北海道大学〕

\section{文 献}

(1) Shibuichi, S., Onda, T., Satoh, N. and Tsujii, K., Super Water-repellent Surfaces Resulting from Fractal Structure, J. Phys. Chem., 100 (1996), 19512-19517.

(2) Tsujii, K., Yamamoto, T., Onda, T. and Shibuichi, S., Super Oil-repellent Surfaces, Angew. Chem. Int. Ed., 36 (1997), 10111012.

(3) Yan, H., Kurogi, K., Mayama, H. and Tsujii, K., Environmentally Stable Super Waterrepellent Poly (alkylpyrrole) Films, Angew Chem. Int. Ed., 44 (2005), 3453-3456. 